\title{
Growth and Physiological Response to Nitrogen Deficiency and Re-supply in Leaf-vegetable Sweetpotato (Ipomoea batatas Lam)
}

\author{
Meng Wei \\ Xuzhou Institute of Agricultural Sciences of the Xuhuai District of Jiangsu \\ Province/Xuzhou Sweetpotato Research Center of Jiangsu Province, Xuzhou \\ 221131, China; and College of Resources and Environment, Shandong \\ Agricultural University, 61 Daizong Street, Tai'An 271018, China
}

\begin{abstract}
Aijun Zhang ${ }^{1}$, Hongmin Li, Zhonghou Tang, and Xiaoguang Chen Xuzhou Institute of Agricultural Sciences of the Xuhuai District of Jiangsu Province/Xuzhou Sweetpotato Research Center of Jiangsu Province, Xuzhou 221131, China
\end{abstract}

Additional index words. Ipomoea batatas Lam, nitrogen deficiency, amino acid, photosynthesis

\begin{abstract}
Nitrogen (N) is an essential macronutrient limiting plant growth and quality of leaf-vegetable sweetpotato (Ipomoea batatas Lam). The objective of this study was to investigate the effects of $\mathrm{N}$ deficiency and re-supply on growth, physiology, and amino acids in sweetpotato. Two leaf-vegetable sweetpotato cultivars, Pushu 53 and Tainong 71, were subjected to three treatments in hydro-culture: 1) $\mathrm{N}$ sufficiency, 2) $\mathrm{N}$ deficiency, and 3) $\mathrm{N}$ deficiency and subsequently with $\mathbf{N}$ re-supply. Compared with $\mathbf{N}$ sufficiency, $\mathbf{N}$ deficiency caused a decrease in vine growth, carotenoid and chlorophyll content (Chlt), root viability, photosynthesis, and nitrate reductase (NR) activity in both cultivars, but to a great extent in Tainong 71. Whereas $\mathbf{N}$ deficiency increased root growth and glutamine synthetase (GS) activity in both cultivars, and the increase in 'Tainong 71' was more obvious. Re-supply of $\mathrm{N}$ recovered the vine growth, root viability, Chlt, photosynthesis, NR, and GS activity, to a greater extent for 'Pushu 53' than for 'Tainong 71'. $\mathrm{N}$ deficiency significantly decreased essential amino acids, including lysine, phenylalanince, isoleucine, tryptophane, leucine, and valine contents and nonessential amino acids, consisting of glutamic acid, aspartic acid, glycine, argnine, and proline content in both cultivars. These results indicated that the light leaf color leafy sweetpotato 'Tainong 71 ' is sensitive to the $\mathrm{N}$ availability and the dark green leaf color 'Pushu 53' is more tolerant to low $N$, which appear to reflect the differential response of two cultivars to their different adaptability to $\mathbf{N}$ availability.
\end{abstract}

Nitrogen is an essential macronutrient required for plant growth and development (Tabuchi et al., 2007), because it is a major constituent of proteins, nucleotides, as well as chlorophyll and numerous other metabolites and cellular components (Lawlor, 2002). Higher plants acquire the majority of their $\mathrm{N}$ from the environment by nitrate assimilation. Nitrate reduction catalyzed by NR, is the primary step in the nitrate assimilation process and it is essential for the production of ammonium to be incorporated into carbon skeletons for amino acid biosynthesis (Matas et al., 2009). Inorganic $\mathrm{N}$ in the soil, in the form of nitrate and ammonia, is initially

\footnotetext{
Received for publication 13 Feb. 2015. Accepted for publication 7 Mar. 2015.

This work was financially supported by the Fund for Independent Innovation of Agricultural Sciences in Jiangsu Province [Grant No. CX (12) 5078], the China Agriculture Research System of Sweetpotato (Grant No. CARS-11-B-13).

${ }^{1}$ To whom reprint requests should be addressed; e-mail zhangaijun608@163.com.
}

converted into glutamine and glutamate by two enzymes, GS and glutamate synthase. These amino acids are then used as starting materials for the biosynthesis of organic compounds involving $\mathrm{N}$, including other amino acids, nucleotides, and chlorophyll (Hirel and Lea, 2002).

Plants usually can become $\mathrm{N}$ deficiency in the field during intervals between fertilizer applications, and one of the main adaptive responses is the reprogramming of growth and metabolism. For many species it results in increased root growth relative to shoots (Smolders and Merckx, 1992). It has been found that low $\mathrm{N}$ nutrition modifies enzyme activities and metabolite contents in plants (Lemaitre et al., 2008). Similarly, NR activity decreased whereas GS activity increased due to higher accumulation of the cytosolic isoform. In Arabidopsis plants grown under limiting N, rosette leaves show an accumulation of sugars while having a deficit in free amino acids (Lemaitre et al., 2008). In addition, $\mathrm{N}$ deficiency hastens senescence due to a high $\mathrm{C}: \mathrm{N}$ ratio (Gombert et al., 2006; Wingler et al., 2006). After a prolonged
$\mathrm{N}$ starvation period, different physiological processes such as nucleic acid and enzyme breakdown occur (Crafts-Brandner et al., 1998). In particular, breakdown of Rubisco leads to a decrease in photosynthetic capacity of the plant and ultimately inhibits plant growth (Walker et al., 2001).

Sweetpotato (I. batatas Lam) belongs to the family Convolvulaceae, and has become the most widely distributed crop in most developing countries. Sweetpotato serves as a staple food (fleshy roots and tender leaves), which is high in nutritive value, outranking most carbohydrate foods in vitamins, minerals, protein, and energy content (Onuh et al., 2004). The leaves of sweetpotato have been shown to be an excellent source of antioxidative polyphenolics such as caffeoylquinic acid, anthocyanins (Islam et al., 2002), as well as beta-carotene compared with other commercial vegetables. Soil $\mathrm{N}$ availability is an important component in storage root production of sweetpotato as well as for leafy sweetpotato (Phillips et al., 2005), whereas $\mathrm{N}$ is an important factor in determining the growth and nutrient composition of leafvegetable sweetpotato. Growth analysis and performance of four sweetpotato cultivars under different levels of $\mathrm{N}$ and $\mathrm{K}$ (potassium) showed that cultivars differed for most of the parameters evaluated: fresh and dry weight of leaves, stems and roots, stem length, internode distance, leaf area, $\mathrm{N}$ and $\mathrm{K}$ contents, and soluble solid levels (Nin and Gilsanz, 1998). So far, little has been known about the $\mathrm{N}$ deficiency and $\mathrm{N}$ re-supply on growth and quality of leaf-vegetable sweetpotato. Therefore, the objectives of this study were to 1) investigate the effect of $\mathrm{N}$ deficiency and subsequently N-resupply on growth, photosynthesis and related physiological processes such as chlorophyll content (Chlt), root viability, $\mathrm{N}$ metabolism in sweetpotato seedlings, and 2) examine variations of amino acids in leaves.

\section{Materials and Methods}

Plant materials, growth conditions, and treatments. Quartz sand (2-4 $\mathrm{mm})$ was pretreated with dilute hydrochloric acid (1:1) for $24 \mathrm{~h}$, washed thoroughly with tap water and followed by three successive deionized water rinses, and then air-dried at room temperature. Uniform vines (seedling length with $20 \mathrm{~cm}$ ) of two leaf-vegetable sweetpotato cultivars with contrasting leaf color, Pushu 53 (dark green) and Tainong 71 (light green), were collected from field and planted in plastic pots $(10 \mathrm{~cm}$ diameter and $12 \mathrm{~cm}$ height). Each pot contained two seedlings with totally 12 pots for each cultivar. Pots filled with quartz sand as the plant anchor medium and suspended over tubs containing $45 \mathrm{~L}$ half-strength Hoagland solution (Hoagland and Arnon, 1950). Pot bottoms consisted of a coarse nylon screen allowing roots to freely growing into the solutions. The culture solution containing $1.44 \mathrm{mM} \mathrm{NH}_{4} \mathrm{NO}_{3}$, $0.3 \mathrm{~mm} \mathrm{NaH} \mathrm{PO}_{4}, 0.5 \mathrm{~mm} \mathrm{~K} \mathrm{SO}_{4}, 1.0 \mathrm{~mm}$ $\mathrm{CaCl}_{2}, 1.6 \mathrm{~mm} \mathrm{MgSO}_{4}, 0.17 \mathrm{~mm} \mathrm{Na} \mathrm{SiO}_{3}$, 
$50 \mu \mathrm{M}$ Fe-EDTA, $0.06 \mu \mathrm{M}\left(\mathrm{NH}_{4}\right)_{6} \mathrm{Mo}_{7} \mathrm{O}_{24}$, $15 \mu \mathrm{M} \mathrm{H}_{3} \mathrm{BO}_{3}, 8 \mu \mathrm{M} \mathrm{MnCl}_{2}, 0.12 \mu \mathrm{M} \mathrm{CuSO}_{4}$, $0.12 \mu \mathrm{M} \mathrm{ZnSO}_{4}, 29 \mu \mathrm{M} \mathrm{FeCl}_{3}$, pH 6.0 (Ning et al., 2014). The culture solution was refreshed every $2 \mathrm{~d}$. Plants were grown in an environmentally controlled walk-in growth room with the temperature regime of $30 / 25{ }^{\circ} \mathrm{C}$ (day/ night), $70 \%$ to $80 \%$ relative humidity, and photosynthetically active radiation (PAR) levels of $1000 \mu \mathrm{mol} \cdot \mathrm{m}^{-2} \cdot \mathrm{s}^{-1}$ at canopy height for $14 \mathrm{~h}$. Plants were allowed to growing for three new leaves expanded in hydro-culture. Then, eight pots of the plants were transferred into a culture solution without $\mathrm{NH}_{4} \mathrm{NO}_{3}$ (N-deficient) and the other four pots transferred into a culture solution with complete nutrients (N-sufficient). After $10 \mathrm{~d}$, four pots of the $\mathrm{N}$-deficient plants were transferred into the culture solution with complete nutrients (N-resupply) and the rest of four pots still in a culture solution without $\mathrm{NH}_{4} \mathrm{NO}_{3}$ (N-deficient). All solutions were changed thrice weekly and deionized water was added daily to replace the water lost by evapotranspiration. The solution $\mathrm{pH}$ was maintained at 6.0 by addition of concentrated $\mathrm{NaOH}$ solution and the solution was continuously aerated with an air pump to provide $\mathrm{O}_{2}$ and achieve nutrient homogeneity. A completely randomized design was used with four replications (pots).

The growth and physiological variables and fresh samples collections were taken after $10 \mathrm{~d}$ of $\mathrm{N}$ re-supply. The third fully expanded leaves from top were used for gas exchange determination, then harvested and immediately frozen in liquid $\mathrm{N}$ and stored at $-80{ }^{\circ} \mathrm{C}$ for the further analysis, and the shoot tips (the first and second leaf) were collected for amino acid determination.

Measurements. Shoot and root growth were determined as the vine and root length at the initial and the final of the experiment.

Net photosynthetic rate $\left(P_{\mathrm{n}}\right)$, stomotal conductance $\left(g_{\mathrm{S}}\right)$, and transpiration rate $\left(T_{\mathrm{r}}\right)$ were measured before and after exposure of $\mathrm{N}$ treatment. The third fully expanded leaves from top were selected for measuring gas exchanges using an Infrared gas analyzer (IRGA, LI-6400; LI-COR, Inc., Lincoln, NE) between 10 AM and 3 PM. Gas exchange parameters were measured under a $P A R$ of $1000 \mu \mathrm{mol} \cdot \mathrm{m}^{-2} \cdot \mathrm{s}^{-1}$, atmospheric $\mathrm{CO}_{2}$ of 400 $\mu \mathrm{mol} \cdot \mathrm{mol}^{-1}, 75 \%$ relative humidity, and temperature of $28^{\circ} \mathrm{C}$

Total Chlt was extracted in the dark for $72 \mathrm{~h}$ in dimethyl sulphoxide following the procedure described by Hiscox and Israelstam (1979). The absorbance of the leaf extract was measured at 663 and $645 \mathrm{~nm}$ with a spectrophotometer [ultraviolet-2600; SHIMADZU Corporation, Kyoto, Japan] and calculated by the formula described in Arnon (1949).

Roots were washed with deionized water for viability measurements. Root viability was estimated by measuring the activity of dehydrogenase by using the triphenyltetrazolium chloride (TTC) reduction technique (Knievel, 1973; McMichael and Burke, 1994). The activity was based on the dry weight of the root sample, determined after drying in an $80{ }^{\circ} \mathrm{C}$ oven for at least $72 \mathrm{~h}$.

Nitrogen reductase activity was measured according to Yaneva et al. (2002). Leaf and root segments were homogenized in an extraction buffer [5 $\mathrm{mm}$ ethylenediaminetetraacetic acid (EDTA), $5 \mathrm{~mm}$ glutathione, $1 \%(\mathrm{w} / \mathrm{v})$ casein, polyvinylpyrrolidone, and $50 \mathrm{~mm}$ hydroxyethyl piperazineethanesulfonic acid $\mathrm{pH}$ 7.5] and centrifuged at $12000 g_{\mathrm{n}}$ for $10 \mathrm{~min}$. Hundred microliters of the homogenate were added in the assay mixture containing $200 \mu \mathrm{mol} \mathrm{KNO}_{3}$ and $0.2 \mu \mathrm{mol}$ nicotinamide adenine dinucleotide. After incubation at $30{ }^{\circ} \mathrm{C}$ for $20 \mathrm{~min}$, the reaction was finished by the addition of $50 \mu \mathrm{L}$ of $1 \mathrm{~m}$ zinc acetate. The mixture was centrifuged for $5 \mathrm{~min}$ at $7600 g_{\mathrm{n}}$ and the supernatant was used to determine nitrite production by reading the absorbance at $540 \mathrm{~nm}$ after the addition of $1 \%$ sulphanylamide in $1.5 \mathrm{M} \mathrm{HCl}$ and $0.01 \%$ $\mathrm{N}$-(1-naphthyl)-ethylenediammonium dichloride. Nitrate reductase activity is expressed in $\mu \mathrm{mol} \mathrm{NO} / \mathrm{g} \mathrm{FW} / \mathrm{h}$, which refers to $1 \mu \mathrm{mol}$ $\mathrm{NO}_{2}$ produced in $1 \mathrm{~h}$ by $1 \mathrm{~g}$ fresh weight of plant materials.

Enzyme activity of GS was determined as described by Horchani et al. (2010). Fresh leaf tissues $(0.2 \mathrm{~g})$ were ground in $3.0 \mathrm{~mL}$ of $50 \mathrm{~mm}$ Tris- $\mathrm{HCl}$ solution ( $\mathrm{pH} 8.0$ ) containing $2 \mathrm{~mm} \mathrm{MgSO}_{4}, 2 \mathrm{~mm}$ DTT, and $0.4 \mathrm{~m}$ sucrose in an ice-cold mortar with a pestle. The homogenate was centrifuged at $12,000 g_{n}$ for $20 \mathrm{~min}$ at $4{ }^{\circ} \mathrm{C}$. One milliliter of the crude enzyme extract was added to $1.6 \mathrm{~mL}$ assay mixture $(0.6 \mathrm{~mL}$ of $0.25 \mathrm{~mm}$ imidazole- $\mathrm{HCl}$ buffer, $0.4 \mathrm{~mL}$ of $0.3 \mathrm{~mm}$ sodium hydrogen glutamate, $0.4 \mathrm{~mL}$ of $30 \mu \mathrm{M}$ ATP- $\mathrm{Na}$, and $0.2 \mathrm{~mL}$ of $0.5 \mathrm{~mm} \mathrm{MgSO}_{4}$ ). The mixture was incubated for $5 \mathrm{~min}$ at $25{ }^{\circ} \mathrm{C}$. And then, $0.2 \mathrm{~mL}$ of hydroxylamine hydrochloride (a mixture of $1 \mathrm{M}$ hydroxylamine hydrochloride and $1 \mathrm{M} \mathrm{HCl}, 1: 1)$ was added and left standing for $15 \mathrm{~min}$. The reaction was stopped by adding $0.8 \mathrm{~mL} \mathrm{FeCl}_{3}$ solution containing $10 \% \mathrm{FeCl}_{3}, 24 \%$ trichloroacetic acid, and $50 \% \mathrm{HCl}(1: 1: 1)$. For the control tube, $1.0 \mathrm{~mL}$ of $50 \mathrm{~mm}$ Tris- $\mathrm{HCl}$ solution was used instead of the crude enzyme extract. Finally, tubes were all centrifuged at $4000 g_{n}$ for $15 \mathrm{~min}$. The resulting supernatants were measured at $540 \mathrm{~nm}$. Glutamine synthetase activity is expressed in $\mathrm{U} / \mathrm{mg}$ protein $/ \mathrm{h}$.

Amino acids were determined according to the method described by Zhang et al. (2012). Briefly, $0.5 \mathrm{~g}$ of fresh shoot tips was ground into fine powder in liquid $\mathrm{N}$ and extracted with $1.5 \mathrm{~mL} \mathrm{HCl}(0.1 \mathrm{~m})$ at $4{ }^{\circ} \mathrm{C}$ for $8 \mathrm{~h}$. The homogenate were centrifuged at $12,000 g_{\mathrm{n}}$ for $30 \mathrm{~min}$. The supernatant was collected and measured by using a reversedphase high performance liquid chromatography with an Agilent 1100 Series (Agilent Technologies; Atlanta, GA) with the excitation and emission wavelength of $338 \mathrm{~nm}$. Seventeen amino acids were separated on an Eclipse AAA column $(4.6 \times 150 \mathrm{~mm}, 5 \mu \mathrm{m})$ eluted at $40{ }^{\circ} \mathrm{C}$ with a gradient of solution $\mathrm{A}$ (40 $\left.\mathrm{mm} \mathrm{NaH}_{2} \mathrm{PO}_{4}, \mathrm{pH} 7.8\right)$ and buffer B [45\% $(\mathrm{v} / \mathrm{v})$ acetonitrile, $45 \%(\mathrm{v} / \mathrm{v})$ methanol, $10 \%$ $(\mathrm{v} / \mathrm{v}) \mathrm{H}_{2} \mathrm{O}$ ] at a flow rate of $2.0 \mathrm{~mL} \cdot \mathrm{min}^{-1}$ with the following proportions of buffer B: $0 \mathrm{~min}$, $0 \% ; 1.9 \mathrm{~min}, 0 \%$; $18.1 \mathrm{~min}, 57 \%$; $18.6 \mathrm{~min}$, $100 \%$; $22.3 \mathrm{~min}, 100 \%$; $23.2 \mathrm{~min}, 0 \%$; and $30 \mathrm{~min} 0 \%$. The calculations were carried out according to the external mixed amino acid standard solution, including 17 kinds of amino acids.

Statistical analysis. All data were subjected to analysis of variance by using the general linear model procedure of SAS (version 9.2; SAS Institute Inc., Cary, NC) to determine the treatment effects and genotypic variations in growth and physiological response. Treatment means and genotype differences were separated using the Duncan's multiple range tests at $P<0.05$.

\section{Results and Discussion}

Growth response to $N$ deficiency and resupply. Plant shoot and root growth showed differential response to $\mathrm{N}$ availability. In this study, $\mathrm{N}$ deficiency inhibited vine growth and promoted root growth in comparison with the $\mathrm{N}$ sufficient control, thus resulted in an increased root:shoot ratio in both cultivars (Table 1). In contrast, re-supply of $\mathrm{N}$ lead to an increased vine length and a decreased root length when compared with the $\mathrm{N}$ deficiency, and the root:shoot ratio were decreased in both cultivars (Table 1). For the comparison of the two cultivars, however, Pushu 53 had increased vine length, reduced root length, and reduced root:shoot ratio in $\mathrm{N}$ deficiency. These results suggested that sweetpotato cultivars with light leaf color are more sensitive to $\mathrm{N}$ availability for growth response. It was evident that leaf production was directly related to vine length. This was clear from the fact that $\mathrm{N}$ deficiency produced the shorter vine and consequently the less

Table 1. Effects of nitrogen $(\mathrm{N})$ treatment on vine and root growth in sweetpotato.

\begin{tabular}{lccc}
\hline & Vine length $(\mathrm{cm})$ & Root length $(\mathrm{cm})$ & Root:shoot ratio \\
'Tainong 71' & & 0.52 \\
S-N & $54.3 \mathrm{a}$ & $28.4 \mathrm{~d}$ & 1.52 \\
D-N & $28.5 \mathrm{~d}$ & $43.3 \mathrm{a}$ & 0.89 \\
R-N & $39.4 \mathrm{bc}$ & $35.1 \mathrm{bc}$ & 0.51 \\
'Pushu 53' & & $30.1 \mathrm{~d}$ & 1.08 \\
S-N & $59.6 \mathrm{a}$ & $38.1 \mathrm{~b}$ & 0.76 \\
D-N & $35.2 \mathrm{c}$ & $34.3 \mathrm{c}$ & \\
R-N & $45.3 \mathrm{~b}$ & & \\
\hline
\end{tabular}

$\mathrm{S}-\mathrm{N}=$ sufficient $\mathrm{N} ; \mathrm{D}-\mathrm{N}=$ deficient $\mathrm{N} ; \mathrm{R}-\mathrm{N}=$ re-supply of $\mathrm{N}$.

Data are expressed as means of four replicates $(n=4)$. Means in a column followed by the same lowercase letter for the comparison of $\mathrm{N}$ treatments for two cultivars are not significant at $P>0.05$ using the Duncan's multiple range tests. 
number of leaves with a lower production for leaf-vegetable sweetpotato. This reduction in traits related to shoot growth and development also has been observed in previous studies that the sessile plant increases its capacity to acquire $\mathrm{N}$ by stimulating root growth relative to shoot growth, which leads to an increased root:shoot ratio and a strong modification of the root system architecture (Richard-Molard et al., 2008; Scheible et al., 1997). One of the possible explanations is that plants allocate exogenous resources toward the biomass production of organs that are involved in acquiring the scarcest nutrients (Remans et al., 2006; Scheible et al., 1997). The root is devoted to mineral nutrient acquisition and it is the first organ that senses and signals mineral starvation. This mechanism has been observed to varying degrees in a wide range of plant species and served as an important step in a plant's ability to compete with its neighbors for a limited supply of nutrients (Ericsson, 1995).

Physiological response to $N$ deficiency and re-supply. Chlorophyll and carotenoid content is one of the most commonly used indicators of leaf senescence (Lim et al., 2007) and the most general symptom of $\mathrm{N}$ deficiency is leaf chlorosis (Marschner, 1995). In this study, 'Pushu 53' had a significantly higher carotenoid and Chlt content under normal growth conditions ( $\mathrm{N}$ sufficiency) (Fig. 1). Sweetpotato seedlings growing under deficient nutrient solutions for $10 \mathrm{~d}$ decreased the contents of chlorophyll in two cultivars and chlorosis was first visually observed in the third leaves, whereas re-supply of $\mathrm{N}$ increased carotenoid and Chlt in comparison with $\mathrm{N}$ deficiency, but still lower than $\mathrm{N}$ sufficiency except for Chlt in 'Pushu 53' (Fig. 1). It appears that analyses of chlorophyll in the third leaf are accurate tools to diagnose $\mathrm{N}$ deficiency in sweetpotato.

In addition, Chlt as an indicator of photosynthetic activity is of particular significance to precision in agriculture (Milivojević and Stojanović, 2003). In this study, along with the decreased Chlt, net $P_{\mathrm{n}}, g_{\mathrm{S}}$, and $T_{\mathrm{r}}$ decreased under $\mathrm{N}$ deficiency when compared with $\mathrm{N}$ sufficiency in both cultivars (Table 2). Whereas re-supply of $\mathrm{N}$ increased $P_{\mathrm{n}}, g_{\mathrm{S}}$, and $T_{\mathrm{r}}$ in two cultivars in comparison with $\mathrm{N}$ deficiency. The gas exchange parameters recovered to the $\mathrm{N}$ sufficient control level in 'Pushu 53', but still lower the control in 'Tainong 71' (Table 2). These results suggested that the reduction of photosynthesis is related, at least partially to the decreased Chlt due to $\mathrm{N}$ deficiency in sweetpotato. There often exists a pronounced down-regulation of photosynthesis in starch-accumulating species when sink capacity is limiting (Goldschmidt and Huber, 1992), which is indicated in this study by reduced vine growth and leaf initiation (Table 1). These results demonstrated that $\mathrm{N}$ deficiency induced sink limitation within the whole plant due to decreased growth and reduced leaf area contributed to the photosynthesis reduction.

Root viability reflects the quality and metabolic status of root development in a certain extent (Liu et al., 2014). In this study, root viability determined by TTC reduction in response to $\mathrm{N}$ treatment in both plant cultivars (Fig. 2). N deficiency reduced root viability in two cultivars, and the reduction in root viability was greater for Tainong 71, since the TTC reduction was reduced to $43 \%$ of the control level in Tainong 71 and by $\approx 74 \%$ in Pushu53. These results suggested that root viability was associated with $\mathrm{N}$ availability for sweetpotato and the tolerance to low N of 'Pushu 53' could be attributed to the high root viability. It has been found that root viability was significantly positively correlated with green leaf area per plant, Chlt, and $P_{\mathrm{n}}$ in soybean under $\mathrm{N}$ fertilization (Zhang et al., 2013). Root viability recovered to some extent in 'Tainong 71', while recovered to the $\mathrm{N}$ sufficient control in 'Pushu 53' after re-supply of N. Root viability did not differ between the two cultivars under the control conditions, but were significantly greater in Pushu 53 than Tainong 71 during $\mathrm{N}$ treatment (Fig. 2). These results indicated that the increased root viability could help to enhance Chlt and $P_{\mathrm{n}}$ in sweetpotato after $\mathrm{N}$ deficiency.

In higher plants, GS and NR are major enzymes responsible for assimilation of ammonium and nitrate absorbed from the growth medium (Lea and Miflin, 1974). In this study, $\mathrm{N}$ deficiency and re-supply significantly modified activity of these two $\mathrm{N}$ assimilating enzymes. The NR activity significantly decreased under $\mathrm{N}$ deficiency in leaves and roots of two cultivars (Table 3 ). The activity of NR recovered to the control level after re-supply of $\mathrm{N}$ in 'Pushu 53', but still lower than the control in 'Tainong 71'. 'Pushu 53' maintained a significantly higher NR activity than 'Tainong 71' under $\mathrm{N}$ deficiency and subsequently $\mathrm{N}$ re-supply suggesting 'Pushu 53' had a higher $\mathrm{N}$ assimilating rate that contribute to the higher tolerance to low N. The enzyme GS plays an important role in $\mathrm{N}$ assimilation and remobilization during senescence (Bernard and Habash, 2009; Miflin and Habash, 2002), and a decrease of leaf GS activity during senescence of rice leaves and the decrease in leaf GS activity were mainly caused by a decrease of the GS2 in the chloroplasts (Kamachi et al., 1991). There was a significant decrease in GS activity in leaves and roots of the seedlings for 'Tainong 71' under $\mathrm{N}$ deficiency, and recovered to the control level after re-supply of $\mathrm{N}$ (Table 3), suggesting a lower level of $\mathrm{N}$ assimilation and remobilization in 'Tainong 71' under $\mathrm{N}$ deficient conditions that leads to the early leaf senescence. We observed a sustained GS activity even under severe N-depleted condition for 'Pushu 53', re-supply of ammonium and nitrate resulted in an increased GS activity, suggesting that nitrate and ammonium supply increases the capacity of nitrite reduction in plastids, and, hence, the demand for higher plastid ammonium assimilation (Tobin and Yamaya, 2001). Interestingly, NR and GS activity was significantly higher in leaves than in roots for both cultivars either under control conditions or $\mathrm{N}$ treatment (Table 3 ), suggesting that the $\mathrm{NO}_{3}{ }^{-}$and $\mathrm{NH}_{4}{ }^{+}$assimilation in sweetpotato primarily occurs in the roots, which was consistent with what has been observed for wheat plants and for many other plant species, but contrary to what has
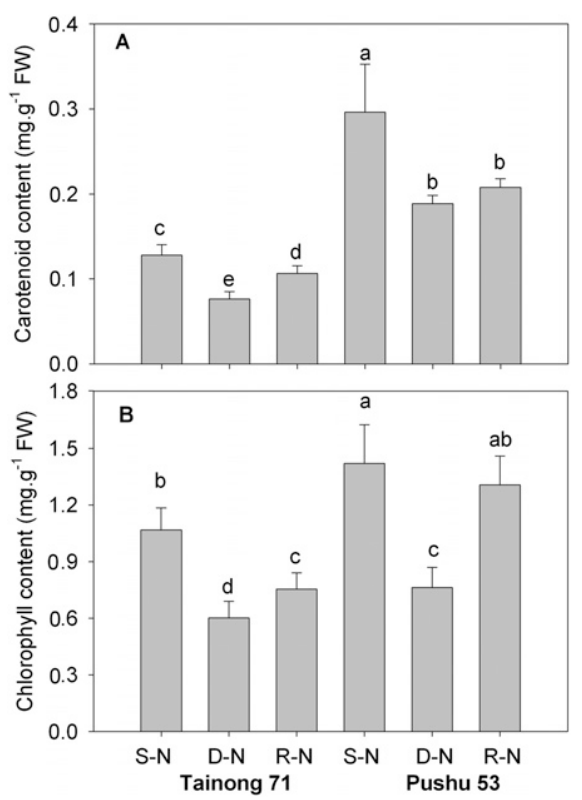

Fig. 1. Effects of nitrogen $(\mathrm{N})$ treatment on carotenoid (A) and chlorophyll (B) content in two sweetpotato cultivars. Plants were treated with a nutrient solution containing sufficient $\mathrm{N}(\mathrm{S}-\mathrm{N})$, deficient N (D-N), and re-supply N (R-N) after N deficiency for $10 \mathrm{~d}$. A bar represents the mean of six replications and the vertical line on top of the bar represents the SD. Treatment means and genotype differences were separated using the Duncan's multiple range tests at $P<0.05$.

Table 2. Effects of nitrogen $(\mathrm{N})$ treatment on leaf net photosynthetic rate $\left(P_{\mathrm{n}}\right)$, stomotal conductance $\left(g_{\mathrm{S}}\right)$, and transpiration rate $\left(T_{\mathrm{r}}\right)$ in sweetpotato.

\begin{tabular}{lcccc}
\hline & Treatment & $P_{\mathrm{n}}\left(\mu \mathrm{mol} \cdot \mathrm{m}^{-2} \mathrm{~s}^{-1}\right)$ & $g_{\mathrm{S}}\left(\mathrm{mmol} \cdot \mathrm{m}^{-2} \cdot \mathrm{s}^{-1}\right)$ & $T_{\mathrm{r}}\left(\mathrm{mmol}^{\left.-\mathrm{m}^{-2} \cdot \mathrm{s}^{-1}\right)}\right.$ \\
\hline 'Tainong 71' & S-N & $15.7 \mathrm{a}$ & $0.28 \mathrm{ab}$ & $4.86 \mathrm{a}$ \\
& D-N & $7.8 \mathrm{~d}$ & $0.14 \mathrm{~d}$ & $2.10 \mathrm{c}$ \\
'Pushu 53' & R-N & $10.3 \mathrm{c}$ & $0.19 \mathrm{c}$ & $2.91 \mathrm{c}$ \\
& S-N & $16.6 \mathrm{a}$ & $0.33 \mathrm{a}$ & $4.91 \mathrm{a}$ \\
& D-N & $13.3 \mathrm{~b}$ & $0.25 \mathrm{~b}$ & $3.70 \mathrm{~b}$ \\
& R-N & $15.4 \mathrm{a}$ & $0.31 \mathrm{a}$ & $4.23 \mathrm{ab}$ \\
\hline
\end{tabular}

$\mathrm{S}-\mathrm{N}=$ sufficient $\mathrm{N} ; \mathrm{D}-\mathrm{N}=$ deficient $\mathrm{N} ; \mathrm{R}-\mathrm{N}=$ re-supply of $\mathrm{N}$.

Data are expressed as means of four replicates $(n=4)$. Means in a column followed by the same lowercase letter for the comparison of $\mathrm{N}$ treatments for two cultivars are not significant at $P<0.05$ using the Duncan's multiple range tests. 
been observed in tomato and lucerne plants (Cruz et al., 1993; Lasa et al., 2002).

The amino acid pool of plants is characterized by high flexibility and varies between

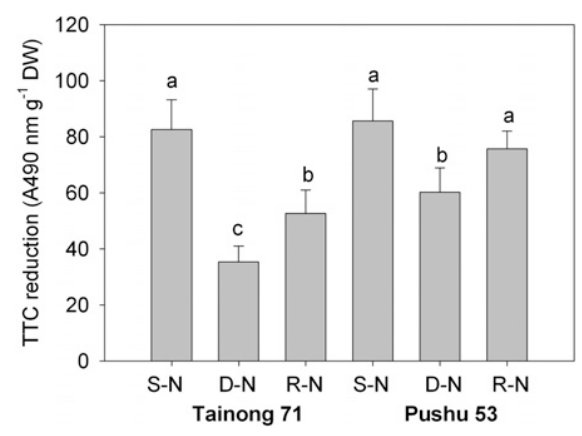

Fig. 2. Effects of nitrogen $(\mathrm{N})$ treatment on root viability [triphenyltetrazolium chloride (TTC) reduction] in two sweetpotato cultivars. Plants were treated with a nutrient solution containing sufficient $\mathrm{N}(\mathrm{S}-\mathrm{N})$, deficient $\mathrm{N}(\mathrm{D}-\mathrm{N})$, and resupply $\mathrm{N}(\mathrm{R}-\mathrm{N})$ after $\mathrm{N}$ deficiency for $10 \mathrm{~d}$. A bar represents the mean of six replications and the vertical line on top of the bar represents the SD. Treatment means and genotype differences were separated using the Duncan's multiple range tests at $P<0.05$.

Table 3. Effects of nitrogen $(\mathrm{N})$ treatment on leaf and root nitrate reductase $(\mathrm{NR})$ and glutamine synthetase (GS) activity in sweetpotato.

\begin{tabular}{|c|c|c|c|c|c|c|}
\hline & \multicolumn{3}{|c|}{ 'Tainong 71' } & \multicolumn{3}{|c|}{ 'Pushu 53' } \\
\hline & \multicolumn{6}{|c|}{$\mathrm{NR}\left(\mathrm{nmol} \mathrm{NO}{ }^{-} / \mathrm{mg}\right.$ protein/h) } \\
\hline & S-N & D-N & $\mathrm{R}-\mathrm{N}$ & S-N & D-N & $\mathrm{R}-\mathrm{N}$ \\
\hline Leaf & $123.4 \mathrm{Aa}$ & $42.3 \mathrm{Ad}$ & $85.4 \mathrm{Ac}$ & $136.4 \mathrm{Aa}$ & $100.3 \mathrm{Abc}$ & $115.4 \mathrm{Aab}$ \\
\hline Root & $83.4 \mathrm{Bb}$ & $22.3 \mathrm{Bd}$ & $\begin{array}{r}46.4 \mathrm{Bc} \\
\mathrm{GS}(\mathrm{U}\end{array}$ & $\begin{array}{r}96.4 \mathrm{Ba} \\
\text { protein } / \mathrm{h})\end{array}$ & $84.3 \mathrm{Bab}$ & $88.4 \mathrm{Bab}$ \\
\hline Leaf & $254.4 \mathrm{Ac}$ & $370.2 \mathrm{Aa}$ & $300.5 \mathrm{Ab}$ & $286.3 \mathrm{Abc}$ & $423.3 \mathrm{Aa}$ & $324.3 \mathrm{Ab}$ \\
\hline Root & $147.0 \mathrm{Bc}$ & $234.5 \mathrm{Ba}$ & $167.9 \mathrm{Bb}$ & 156.2 Bbc & $164.8 \mathrm{Bb}$ & 158.2 Bbc \\
\hline
\end{tabular}

$\mathrm{S}-\mathrm{N}=$ sufficient $\mathrm{N} ; \mathrm{D}-\mathrm{N}=$ deficient $\mathrm{N} ; \mathrm{R}-\mathrm{N}=$ re-supply of $\mathrm{N}$.

Data are expressed as means of four replicates $(n=4)$. Means in a column followed by the same uppercase letters for the comparison of leaf and root are not significant; values followed by the same letters in a row indicate no significant differences between $N$ treatments for two cultivars at $P<0.05$ using the Duncan's multiple range tests. species, cell types, and physiological situations (Schlüter et al., 2012). The majority of amino acids usually change in coordination; especially high correlation had been described for minor amino acids (Noctor et al., 2002) or amino acids sharing the same biosynthetic pathway (Fritz et al., 2006). In this study, $\mathrm{N}$ deficiency significantly decreased essential amino acids, including Lys, Phe, isoleucine (Ile), tryptophane (Trp), leucine (Leu), and valine (Val) content, and nonessential amino acids, consisting of glutamic acid (Glu), aspartic acid (Asp), Gly, argnine (Arg), and proline (Pro) content in both cultivars (Table 4). The general downregulation of amino acids in $\mathrm{N}$-starved plants is expected and in agreement with many other studies in perennial ryegrass (Louahlia et al., 2008), Arabidopsis (Krapp et al., 2011), wheat (Howarth et al., 2008), tomato (Urbanczyk-Wochniak and Fernie, 2005), and tobacco (Fritz et al., 2006). Under control growth conditions ( sufficient N, S-N), 'Pushu 53' had higher lysine (Lys), phenylalanince (Phe), glycine (Gly), and histidine (His) content than 'Tainong 71' (Table 4). There was no difference between $\mathrm{N}$ deficiency and the $\mathrm{N}$ sufficiency for the essential amino acids methionine (Met), threonine (Thr), and nonessential amino acids serine (Ser), His, Ala, and tyrosine (Tyr) content in two cultivars. In contrast, re-supply of $\mathrm{N}$ increased essential amino acid content, including Lys, Phe, Ile, Trp, Leu, and Val content, and nonessential amino acids including Glu, Asp, Arg, and Pro content when compared with the $\mathrm{N}$ deficiency in two cultivars. It is remarkable that the essential amino acids including Lys, Phe, Ile, and Val content, and nonessential amino acids including Glu, Asp, Arg, and Pro content was higher in leaves of 'Pushu 53' than that of 'Tainong 71 ' under $\mathrm{N}$ deficiency and re-supply (Table 4). In contrast to the majority of amino acids, Ala and Tyr showed no changes under $\mathrm{N}$ deficiency for two cultivars, even a decreased level was observed for 'Tainong 71' after resupply of N. In the study of Tschoep et al. (2009), only Asp, Ala, and Asn decreased under low $\mathrm{N}$, but most other amino acids increased. These results suggested that growth retardation was due to changes in sink demand and allowed accumulation of amino acids under $\mathrm{N}$ stress. Strong individual responses to low- $\mathrm{N}$ conditions were also found for Lys and Leu in tomato leaves (UrbanczykWochniak and Fernie, 2005), for Gln and Trp in wheat (Howarth et al., 2008), and for Glu, Phe, and Asp in tobacco leaves (Fritz et al., 2006). It shows that under specific experimental conditions, the response of individual amino acids differs not only quantitatively but also qualitatively from the general trend (Schlüter et al., 2012).

In summary, $\mathrm{N}$ deficiency caused growth retardation and accelerated leaf senescence as indicated by the decline in vine growth, photosynthesis, root viability, $\mathrm{N}$ assimilating enzymes, Chlt and amino acid content in leaves, with more great changes in 'Tainong 71'. These results indicated that 'Tainong 71' was sensitive to $\mathrm{N}$ availability and 'Pushu 53' was more tolerant to low $\mathrm{N}$, which appeared

Table 4. Effect of nitrogen $(\mathrm{N})$ treatment on leaf amino acids content $\left(\mathrm{mg} \cdot \mathrm{kg}^{-1}\right)$ in two cultivars of sweetpotato.

\begin{tabular}{|c|c|c|c|c|c|c|}
\hline & \multicolumn{3}{|c|}{ Tainong 71} & \multicolumn{3}{|c|}{ Pushu 53} \\
\hline & $\mathrm{S}-\mathrm{N}$ & $\mathrm{D}-\mathrm{N}$ & $\mathrm{R}-\mathrm{N}$ & S-N & D-N & $\mathrm{R}-\mathrm{N}$ \\
\hline \multicolumn{7}{|c|}{ Essential amino acids } \\
\hline Lysine & $1881 \mathrm{~b}$ & $583 \mathrm{e}$ & $1505 \mathrm{c}$ & $2073 \mathrm{a}$ & $1057 \mathrm{~d}$ & $1907 \mathrm{ab}$ \\
\hline Phenylalanine & $1672 \mathrm{~b}$ & $853 \mathrm{~d}$ & $1338 \mathrm{c}$ & $1875 \mathrm{a}$ & $1444 \mathrm{c}$ & $1725 \mathrm{ab}$ \\
\hline Methionine & $523 \mathrm{a}$ & $528 \mathrm{a}$ & 496 a & $592 \mathrm{a}$ & $563 \mathrm{a}$ & $545 \mathrm{a}$ \\
\hline Threonine & $1463 \mathrm{ab}$ & $1419 \mathrm{ab}$ & $1375 \mathrm{~b}$ & $1579 \mathrm{a}$ & $1516 \mathrm{a}$ & $1453 \mathrm{ab}$ \\
\hline Isoleucine & $1359 \mathrm{ab}$ & $693 c$ & $1087 \mathrm{~b}$ & $1481 \mathrm{a}$ & $1081 \mathrm{~b}$ & $1362 \mathrm{ab}$ \\
\hline Tryptophane & $314 \mathrm{a}$ & $169 \mathrm{c}$ & $251 \mathrm{~b}$ & $296 \mathrm{ab}$ & $252 \mathrm{~b}$ & $272 \mathrm{ab}$ \\
\hline Leucine & $2613 \mathrm{a}$ & $1620 \mathrm{c}$ & $2090 \mathrm{~b}$ & $2862 \mathrm{a}$ & $2175 \mathrm{~b}$ & $2633 \mathrm{a}$ \\
\hline Valine & $2090 \mathrm{a}$ & $1066 \mathrm{~d}$ & $1672 \mathrm{~b}$ & $1875 \mathrm{ab}$ & $1369 \mathrm{c}$ & $1725 \mathrm{ab}$ \\
\hline \multicolumn{7}{|c|}{ Nonessential amino acids } \\
\hline Glutamic acid & $4285 \mathrm{a}$ & $2185 \mathrm{c}$ & $3428 \mathrm{~b}$ & $4540 \mathrm{a}$ & $3314 b$ & $4177 \mathrm{ab}$ \\
\hline Serine & $1254 \mathrm{ab}$ & $1141 \mathrm{~b}$ & $1279 \mathrm{ab}$ & $1283 \mathrm{ab}$ & $1501 \mathrm{a}$ & $1180 \mathrm{~b}$ \\
\hline Aspartic acid & $3553 \mathrm{a}$ & $1812 \mathrm{c}$ & $2842 \mathrm{~b}$ & $3652 \mathrm{a}$ & $1132 \mathrm{~d}$ & $3360 \mathrm{ab}$ \\
\hline Glycine & $1672 \mathrm{~b}$ & $1488 \mathrm{c}$ & $1338 \mathrm{~d}$ & $1974 \mathrm{a}$ & $1441 \mathrm{c}$ & $1816 \mathrm{ab}$ \\
\hline Argnine & $1986 \mathrm{a}$ & $1154 \mathrm{~d}$ & $1588 \mathrm{~b}$ & $2073 \mathrm{a}$ & $1264 \mathrm{c}$ & $2011 \mathrm{a}$ \\
\hline Proline & $1463 \mathrm{a}$ & $600 \mathrm{c}$ & $1170 \mathrm{~b}$ & $1481 \mathrm{a}$ & $1081 \mathrm{~b}$ & $1451 \mathrm{a}$ \\
\hline Histidine & $732 \mathrm{~b}$ & $783 \mathrm{~b}$ & $585 \mathrm{~d}$ & $888 \mathrm{a}$ & $648 \mathrm{c}$ & $835 \mathrm{ab}$ \\
\hline Alanine & $1881 \mathrm{a}$ & $1994 \mathrm{a}$ & $1505 \mathrm{~b}$ & $1974 \mathrm{a}$ & $1816 \mathrm{a}$ & $1836 \mathrm{a}$ \\
\hline Tyrosine & $1045 \mathrm{a}$ & $1003 \mathrm{a}$ & $836 \mathrm{~b}$ & $1184 \mathrm{a}$ & $1094 \mathrm{a}$ & $1090 \mathrm{a}$ \\
\hline
\end{tabular}

$\mathrm{S}-\mathrm{N}=\mathrm{N}$ sufficiency; $\mathrm{D}-\mathrm{N}=\mathrm{N}$ deficiency; R-N = re-supply of $\mathrm{N}$.

Data are expressed as means of four replicates $(n=4)$. Values followed by the same letters in a row means no significant differences between $\mathrm{N}$ treatments for two cultivars at $P<0.05$ using the Duncan's multiple range tests. 
to reflect the differential response of two cultivars to their different adaptability to $\mathrm{N}$ availability and might have evolved as an important strategy of survival of these cultivars in their natural environment.

\section{Literature Cited}

Arnon, D.I. 1949. Copper enzymes in isolated chloroplasts, polyphenoloxidase in Beta vulgaris. Plant Physiol. 24:1-15.

Bernard, S.M. and D.Z. Habash. 2009. The Importance of cytosolic glutamine synthe-tasein nitrogen assimilation and recycling. New Phytol. 182:608-620.

Crafts-Brandner, S.J., R. Hölzer, and U. Feller. 1998. Influence of nitrogen deficiency on senescence and the amounts of RNA and proteins in wheat leaves. Physiol. Plant. 102:192-200.

Cruz, P., N.M. Munier-Jolain, R. Tournebize, and H. Sinoquet. 1993. Growth and mineral nutrition in a Dichanthium aristatum sward shaded by trees. Proc. XVII I.G.C., New ZealandAustralia, 2056-2057.

Ericsson, T. 1995. Growth and shoot:root ratio of seedlings in relation to nutrient availability. Plant Soil 168-169:205-214.

Fritz, C., N. Palacios-Rojas, R. Feil, and M. Stitt. 2006. Regulation of secondary metabolism by carbon-nitrogen status in tobacco: Nitrate inhibits large sectors of phenylpropanoid metabolism. Plant J. 46:533-548.

Goldschmidt, E.E. and S.C. Huber. 1992. Regulation of photosynthesis by end-product accumulation in leaves of plants storing starch, sucrose, and hexose sugars. Plant Physiol. 99:1443-1448.

Gombert, J., P. Etienne, A. Ourry, and F. Le Dily. 2006. The expression patterns of SAG12/Cab genes reveal the spatial and temporal progression of leaf senescence in Brassica napus $\mathrm{L}$. with sensitivity to the environment. J. Expt. Bot. 57:1949-1956.

Hirel, B. and P.J. Lea. 2002. The biochemistry, molecular biology, and genetic manipulation of primary ammonia assimilation. In: C.H. Foyer and G. Noctor (eds.). Advances in photosynthesis and respiration, Vol. 12, Photosynthetic nitrogen assimilation and associated carbon and respiratory metabolism. Kluwer, Dordrecht, The Netherlands.

Hiscox, J.D. and G.F. Israelstam. 1979. A method for the extraction of chlorophyll from leaf tissue without maceration. Can. J. Bot. 57:1332-1334.

Hoagland, D.R. and D.I. Arnon. 1950. The waterculture method for growing plants without soil. California Agr. Exp. Sta. Circ. 347:1-32.

Horchani, F., S. Aschi-Smiti, and R. Brouquisse. 2010. Involvement of nitrate reductase in the tolerance of tomato (Solanum lycopersicum L.) plants to prolonged root hypoxia. Acta Physiol. Plant. 32:1113-1123.

Howarth, J.R., S. Parmar, J. Jones, C.E. Shepherd, D.I. Corol, A.M. Galster, N.D. Hawkins, S.J. Miller, J.M. Baker, and P.J. Verrier. 2008. Coordinated expression of amino acid metabolism in response to $\mathrm{N}$ and $\mathrm{S}$ deficiency during wheat grain filling. J. Expt. Bot. 59:3675-3689.

Islam, M.S., M. Yoshimoto, S. Yahara, S. Okuno, K. Ishiguro, and O. Yamakawa. 2002. Identification and characterization of foliar polyphenolic composition in sweetpotato (Ipomoea batatas L.) genotypes. J. Agr. Food Chem. 50:3718-3722.

Kamachi, K., T. Yamaya, T. Mae, and K. Ojima. 1991. A role for glutamine synthetase in the remobilization of leaf nitrogen during natural senescence in rice leaves. Plant Physiol. 96:411-417.

Knievel, D.P. 1973. Procedure for estimating ratio of live and dead root dry matter in root core samples. Crop Sci. 13:124-126.

Krapp, A., R. Berthomé, M. Orsel, S. MerceyBoutet, A. Yu, L. Castaings, S. Elftieh, H. Major, J.P. Renou, and F. Daniel-Vedele. 2011. Arabidopsis roots and shoots show distinct temporal adaptation patterns toward nitrogen starvation. Plant Physiol. 157:1255-1282.

Lasa, B., S. Frechilla, P.M. Aparicio-Tejo, and C. Lamsfus. 2002. Role of glutamate dehydrogenase and phosphoenolpyruvate carboxylase activity in ammonium nutrition tolerance in roots. Plant Physiol. Biochem. 40:969-976.

Lawlor, D.W. 2002. Limitation of photosynthesis in water-stressed leaves: Stomata vs. metabolism and the role of ATP. Ann. Bot. 89:871885.

Lea, P.J. and B.J. Miflin. 1974. Alternative route for nitrogen assimilation in higher plants. Nature 251:614-616.

Lemaitre, T., L. Gaufichon, S. Boutet-Mercey, A. Christ, and C. Masclaux-Daubresse. 2008. Enzymatic and metabolic diagnostic of nitrogen deficiency in Arabidopsis thaliana Wassileskija accession. Plant Cell Physiol. 49:1056-1065.

Lim, P.O., H.J. Kim, and H.G. Nam. 2007. Leaf senescence. Annu. Rev. Plant Biol. 58:115-136.

Liu, J.J., Z. Wei, and J.H. Li. 2014. Effects of copper on leaf membrane structure and root activity of maize seedling. Bot. Stud. 55:47.

Louahlia, S., P. Laine, J.H. MacDuff, A. Ourry, M. Humphreys, and J. Boucaud. 2008. Interactions between reserve mobilization and regulation of nitrate uptake during regrowth of Lolium perenne L.: Putative roles of amino acids and carbohydrates. Botany 86:1101-1110.

Marschner, H. 1995. Mineral nutrition of higher plants, 2nd ed. Academic Press, London, p. 405-435.

Matas, A.J., N.E. Gapper, M.Y. Chung, J.J. Glovannoni, and J.K.C. Rose. 2009. Biology and genetic engineering of fruit maturation for enhanced quality and shelf-life. Curr. Opin. Biotechnol. 20:197-203.

McMichael, B.L. and J.J. Burke. 1994. Metabolic activity of cotton roots in response to temperature. Environ. Expt. Bot. 34:201-206.

Miflin, B.J. and D.Z. Habash. 2002. The role of glutamine synthetase and glutamate dehydrogenase in nitrogen assimilation and possibilities for improvement in the nitrogen utilization of crops. J. Expt. Bot. 53:979-987.

Milivojević, D. and D. Stojanović. 2003. Role of calcium in aluminum toxicity on content of pigments and pigment-protein complexes of soybean. J. Plant Nutr. 26:341-350.

Noctor, G., S. Veljovic-Jovanovic, S. Driscoll, L. Novitskaya, and C.H. Foyer. 2002. Drought and oxidative load in wheat leaves: A predominant role for photorespiration? Ann. Bot. 89:841-850.

Nin, A. and J.C. Gilsanz. 1998. Growth analysis and performance of four sweetpotato cultivars under different levels of nitrogen and potassium. HortScience 33:443-445.

Ning, Y.W., H.B. Ma, X.J. Xu, and J.D. Wang. 2014. Effects of deficiency of N,P or K on growth traits and nutrient uptakes of sweetpotato at early growing stage. Scientia Agricultura Sinica. 46:486-495.

Onuh, J.O., M.A. Aspapunam, and M.O. Iwe. 2004. Comparative studies of the physico-chemical properties of two local varieties of sweetpotato flours. Niggerian Food J. 2:141-146.
Phillips, S.B., J.G. Warren, and G.L. Mullins. 2005. Nitrogen rate and application timing affect 'Beauregard' Sweetpotato tield and quality. HortScience 40:1214-1217.

Remans, T., P. Nacry, M. Pervent, S. Filleur, E. Diatloff, E. Mounier, P. Tillard, B.G. Forde, and A. Gojon. 2006. The Arabidopsis NRT1.1 transporter participates in the signaling pathway triggering root colonization of nitrate-rich patches. Proc. Natl Acad. Sci. USA 103:1920619211.

Richard-Molard, C., A. Krapp, F. Brun, B. Ney, F. Daniel-Vedele, and S. Chaillou. 2008. Plant response to nitrate starvation is determined by $\mathrm{N}$ storage capacity matched by nitrate uptake capacity in two Arabidopsis genotypes. J. Expt. Bot. 59:779-791.

Scheible, W.R., A. González-Fontes, M. Lauerer, B. Müller-Röber, M. Caboche, and M. Stitt. 1997. Nitrate acts as a signal to induce organic acid metabolism and repress starch metabolism in tobacco. Plant Cell 9:783-798.

Schlüter, U., M. Mascher, C. Colmsee, U. Scholz, A. Bräutigam, H. Fahnenstich, and U. Sonnewald. 2012. Maize source leaf adaptation to nitrogen deficiency affects not only nitrogen and carbon metabolism but also control of phosphate homeostasis. Plant Physiol. 160:1384-1406.

Smolders, E. and R. Merckx. 1992. Growth and shoot:root partitioning of spinach plant as affected by nitrogen supply. Plant Cell Environ. 15:795-807.

Tabuchi, M., T. Abiko, and T. Yamaya. 2007. Assimilation of ammonium ions and reutilization of nitrogen in rice (O. sativa L.). J. Expt. Bot. 58:2319-2327.

Tobin, A.K. and T. Yamaya. 2001. Cellular compartmentation of ammonium assimilation in rice and barley. J. Expt. Bot. 52:591-604.

Tschoep, H., Y. Gibon, P. Carillo, P. Armengaud, M. Szecowka, A. Nunes-Nesi, A.R. Fernie, K. Koehl, and M. Stitt. 2009. Adjustment of growth and central metabolism to a mild but sustained nitrogen-limitation in Arabidopsis. Plant Cell Environ. 32:300-318.

Urbanczyk-Wochniak, E. and A.R. Fernie. 2005. Metabolic profiling reveals altered nitrogen nutrient regimes have diverse effects on the metabolism of hydroponically-grown tomato (Solanum lycopersicum) plants. J. Expt. Bot. 56:309-321.

Walker, R.L., I.G. Burns, and J. Moorby. 2001. Responses of plant growth rate to nitrogen supply: A comparison of relative addition and $\mathrm{N}$ interruption treatments. J. Expt. Bot. 52:309-317.

Wingler, A., S. Purdy, J.A. MacLean, and N. Pourtau. 2006. The role of sugars in integrating environmental signals during the regulation of leaf senescence. J. Expt. Bot. 57:391-399.

Yaneva, I.A., G.W. Hoffmann, and R. Tischner. 2002. Nitrate reductase from winter wheat leaves is activated at low temperature via protein dephosphorylation. Physiol. Plant. 114:65-72.

Zhang, P.P., L.X. Hu, and J.M. Fu. 2012. Effects of alkali stress on growth, free amino acids and carbohydrates metabolism in Kentucky bluegrass (Poa pratensis). Ecotoxicology 21:1911-1918.

Zhang, X., G. Huang, X. Bian, and Q. Zhao. 2013. Effects of root interaction and nitrogen fertilization on the chlorophyll content, root activity, photosynthetic characteristics of intercropped soybean and microbial quantity in the rhizosphere. Plant Soil 368:407-417. 